\title{
The Effect Of Attitude, Normal Subjective And Perceived Behav- ioral Control (Pbc) On Actual Purchasing Through Purchases Of Online Purchase In The Online Retail Industry
}

\author{
Anita Heptariza \\ Universitas Warmadewa, Denpasar, Bali \\ Anitariza90@gmail.com
}

\begin{tabular}{|l|}
\hline \multicolumn{1}{|c|}{ Published: 30/03/2020 } \\
\hline How to cite (in APA style): \\
Heptariza, A (2020). The Effect Of Attitude, Normal Subjective And Perceived Behavioral Control (Pbc) On Actual Pur- \\
chasing Through Purchases Of Online Purchase In The Online Retail Industry. Jurnal Ekonomi dan Bisnis Jagaditha, 7(1), \\
9-17. doi: https://doi.org/10.22225/jj.7.1.583.9-17
\end{tabular}

\begin{abstract}
Online shopping activities are currently growing. Online shopping activities are supported by the increasing number of Internet users. With the growing number of people who know the internet and along with the presence of Generation $\mathrm{Z}$ who was born in the digital age make the habit of spending goods and services slowly but surely have to switch online. One of the factors that affect online shopping is the intention of purchasing online. Theory of Planned Behavior (TPB) explains that consumer behavior is shaped by attitudes, subjective norms, and perceived behavioral control (PBC) that form the intention of online purchasing. This study aims to analyze the effect of attitudes on online purchase intentions, to analyze the effect of subjective norms on online purchasing intentions, to analyze the effect of $\mathrm{PBC}$ on online purchase intentions and to analyze the effect of online purchase intentions on actual purchases. The research was conducted at Prama Sanur Beach Hotel. The technique of data collection used are observation, interview, documentation, questionnaires. Data analysis technique using quantitative analysis with PLS program. The results show that attitudes have a positive and significant influence on the intentions of online purchasing. Subjective norms have a positive but insignificant effect on online purchase intentions. Perceived Behavioral Control (PBC) has a positive and significant effect on online purchasing intentions, and online purchase intentions have a positive and significant effect on actual purchases.
\end{abstract}

Keywords: Actual Purchase, attitude, intention Online Purchase, Perceived Behavioral Control (PBC), Subjective Norm

\section{INTRODUCTION}

Indonesia's e-commerce market especially in the retail industry is experiencing a developmental phase. This is reflected in the significant increase in the value of Indonesian e-commerce transactions from year to year. Data released by the Ministry of Communications and Information of the Republic of Indonesia and the Ministry of Trade of the Republic of Indonesia stated that in 2014, the value of e-commerce transactions reached US $\$ 12$ billion, rapidly increased to US $\$ 19$ billion in 2015, in 2016 predicted past US $\$ 20$ billion or above Rp. 250 trillion (Ministry of Trade, 2016). The rapid adoption of the Internet in trading activities is motivated by the benefits of internet technology for suppliers in business and consumers in shopping. Benefits for suppliers include transaction efficiency, low-cost distribution channels, improved customer service through personalized services, reduced costs (Huang \& Hsu, 2009), shortening distribution channels, and increasingly easy and low cost communications (Reino et al., 2011). The same thing happens on the consumer side, where the internet offers practicality in shopping, extensive choice, relatively cheap price, and attractive promo frekuentif (SWA, 2016).

In Indonesia itself, online shopping 
activities are growing, in this case can be seen from the rampant online shopping activities, is also supported by the number of internet users in Indonesia is growing in which in 2016 the number of Internet users in Indonesia is 132.7 million users or about 51.5 percent of the total population of Indonesia amounted to 256.2 million (APJII, 2016). With the growing number of people who know the Internet along with the birth of Generation $\mathrm{Z}$ who was born in the digital age make the habit of shopping goods and services have been turned into being done online. The most consumptive community in the digital realm is the age group of 19-35 years. Approximately 58 percent of the data is dominated by employees, where the most searched products in the online context are fashion products, gadgets and accessories, household products, cosmetics and beauty products and ticket purchases (ukm.com).

Based on the formulation of the above problem, the aims of this study are to analyze the effect of attitudes on online purchase intentions, to analyze the effect of subjective norms on online purchase intentions, to analyze the effect of PBC on online purchase intentions, and to analyze the effect of online purchase intentions on actual purchases

\section{CONCEPT AND HYPOTHESIS}

Theory of Reasoned Action (TRA) was developed by Ajzen and was named Theory of Planned Behavior (TPB) (Lee \& Kotler, 2011). Theory of Planned Behavior is described as a complete construct of TRA. In TRA it is explained that one's intention toward behavior is formed by two main factors: attitude toward behavior and subjective norm (Fishbein, M, \& Ajzen, 1975), whereas in TPB is added one more factor that is Perceived behavioral control (Ajzen, 1991). According to (Lee \& Kotler, 2011), individual targets have a great possibility of adopting a behavior if the individual has a positive attitude toward the behavior, obtaining the consent of another individual who is close and related to the behavior and believes that the behavior it can be done well.

Theory of Planned Behavior (TPB) explains that consumer behavior is shaped by attitudes, subjective norms, and Perceived behavioral control (PBC) that shape intentions. Intention then affects how a person behaves. This theory forms the basis of current studies that analyze the effect of intent on online buying behavior. This model was developed by Icek Ajzen to perfect the predictive power of Theory of Reasoned Action (TRA), by adding the PBC variable. This theory postulates that attitudes, subjective norms, and PBC together form intent and behavior.

The three variables forming the intention in the TPB namely attitude is a person's positive or negative evaluation of a behavior. The concept is the extent to which behavior is judged positive or negative.

Subjective norms is a person's perception of a particular behavior, where this perception is influenced by the judgment of the perceived influential person, such as a parent, spouse, friend, and mentor, and

Perceived behavioral control (PBC) is perceptions about the easy or difficult conduct of certain behaviors. PBC is determined by the presence of factors that can facilitate or hinder a person's ability to perform such behavior. $\mathrm{PBC}$ is conceptually related to self efficacy developed by (Bandura, 1977) in social cognitive theory.

TPB is one of the theories of behavior with high predictive power, and is used to predict human behavior in all areas. The study often uses this theory in marketing (buying behavior, advertising, public relations), behavior in new environments such as online, and in new issues such as eco-friendly products, health (public education), and entrepreneurial behavior. This study analyzes the influence of intention on online purchasing behavior, so TPB is a very important theory as the basis of this research.

Based on the explanation above, therefore, the hypotheses could be formulated as follows:

H1: Leadership positively and significantly affects employee's working spirit at Prama Sanur Beach Hotel.

H2: The work environment has a positive and significant effect on employee morale at Prama Sanur Beach Hotel.

H3: Leadership positively and significantly affects employee performance at Prama Sanur Beach Hotel.

H4: The work environment has a positive and significant impact on performance of Prama Sanur Beach Hotel's employees.

H5: The spirit of work has a positive and significant impact on performance of employees at Prama Sanur Beach Hotel.

H6: mediates leadership influence on performance of employees at Prama Sanur Beach Hotel. 
H7: $\quad$ The spirit of work mediates the influence of the work environment towards performance of employees at Prama Sanur Beach Hotel.

\section{METHOD}

\section{Location and Object of Research}

The research was conducted at Prama Sanur Beach Hotel which is one member of Aerowisata Hotels and Resorts which was established in 1974. This 5-star hotel is very environmentally friendly with a warm and always smiling staff. The hotel is equipped with a variety of unique restaurants and bars, contemporary facilities and activities for the whole family. Consisting of more than 426 rooms spread over 7 hectares of lush tropical gardens, next to sandy beaches with spectacular scenery located on Lake Tamblingan street Sanur.

\section{Population}

Population is a generalization area consists of objects that have certain qualities and characteristics set by the researcher to be studied and then drawn conclusions (Sugiyono, 2013). The population in this study are all employees of Prama Sanur Beach Hotel which amounted to 417 people.

\section{Sample}

(Sugiyono, 2016) stated that the sample is part of the number and characteristics possessed by the population. If large populations and the researcher is unlikely to study everything in the population, for example due to limited funds, manpower and time, the researcher can use sample taken from that population. To determine the sample size of a population in the study used Slovin method in (Umar, 2013) with the formula:

$$
\mathrm{n}=\mathrm{N} / 1+\mathrm{N} \mathrm{e}^{2}
$$

Where

$$
\begin{aligned}
& \mathrm{n}=\text { Number of samples } \\
& \mathrm{N}=\text { Population size }
\end{aligned}
$$

$\mathrm{E}=$ Percent leeway inaccuracy due to sampling errors that can still be tolerated or desirable, in this case $10 \%$.

Thus the sample size is:

$$
\begin{aligned}
& \mathrm{n}=\quad 417 /\left[1+\left(417 \times 0,01^{2}\right)\right] \\
& =\quad 417 / 5,17 \\
& =\quad 80,6576 \\
& =\quad 81 \text { (rounded) }
\end{aligned}
$$

\section{Variable Identification}

Based on the issues that have been described before, the variables to be analyzed can be identified as follows:

Endogenous variable is a variable that is influenced by other variables in the model. In this research which is dependent variable is employee performance (Y2).

Intervening Variable. According to Tuckman in (Sugiyono, 2017) intervening variable is a variable that theoretically affects the relationship between independent variable with dependent variable into an indirect relationship. In this research which is intervening variable is working spirit (Y1).

Exogenous variable is a variable that affects or has an influence on other variables in the model. In this study, the independent variables are leadership (X1) and Work environment (X2).

\section{Operational Definition of Variable}

In order to clarify the variables analyzed, it is necessary to explain the operational definitions for each variable. The definition of operational variables is a step in linking the theory concepts with empirical studies so that mistakes in interpreting the variables analyzed do not occur. The following describes the operational definitions of leadership variables, work environment, working spirit and performance.

\section{Leadership}

Leadership is an activity to influence the behavior of others, or the art of affecting human behavior both individuals and groups (Thoha, 2010). This study measures the leadership of Prama Sanur Beach Hotel based on (Rivai, 2013) indicators:

Telling, the leader's ability to tell employees what to do.

Selling, the leader's ability to sell or give ideas to employees.

Participating, is the ability of leaders to participate with members or employees.

Delegating, is the ability to delegate tasks and authority to employees.

\section{Work Environment}

According to Nitisemito in (Nuraini, 2013) that the work environment is everything that is around employees and can affect in carrying out tasks assigned to him for example in the presence of air conditioner (AC), adequate lighting and so forth.

This study measures the working 
environment at Prama Sanur Beach Hotel based on (Sedarmayanti, 2004) with indicators:

a) Lighting in the workplace

b) Temperatures in the workplace

c) Good humidity and air circulation

d) Air circulation in the workplace

e) Cooperation among departments in the workplace
f) Cleanliness at work
g) Decoration at work
h) Security at work

\section{Spirit of Work}

The spirit of work is to do the job more actively so that work can be expected faster and better (Nitisemito, 2001). The indicator of employee's working spirit variable used in this study refers to (Moekijat, 2002):

Willingness to work together

Obedience to the provisions of the work implementation

Timeliness in completing the work

\section{Performance}

(Mangkunegara, 2007) stated that the performance is the work achievement or output both quality and quantity of human resources achieved per unit time period in carrying out its work duties in accordance with the responsibilities given to him.

Performance indicators used in this study are based on (Mathis \& Jackson, 2006) which stated that in general there are some elements of employee performance, they are:

The quantity of the results, measured from the employee's perception towards the number of activities assigned and the results.

The quality of the results, measured by employee perceptions to the quality of work produced and the perfection of the tasks to the skills and abilities of employees.

Timeliness of results, measured from employee perceptions to an activity completed from the beginning of time until it becomes output. Can finish at predefined time and maximize the time available.

Attendance, the attendance rate of employees within the company can determine employee performance.

Ability to work together, measured from the ability of employees in cooperation with colleagues and the environment.
This data collection is supported through interview and observation process which is then analyzed directly with statistical tools on the answers obtained from the respondents and collected based on the employee's assessment or the employee's answer to each question in the questionnaire submitted. In addition to the above primary data, this study also utilizes existing data in Prama Sanur Beach Hotel in the form of secondary data, relevant as a supporter of data accuracy.

\section{Methods of Data Collection}

To obtain the necessary data in this study are some of the data collection techniques below:

\section{Observation}

Observation is data collection by conducting direct observation of leadership, work discipline and work environment on employee performance.

\section{Interview}

Interview is a method of data collection by means of direct interview with the leadership of the company or with employees in the company to obtain information relating to research.

\section{Documentation of Research}

Documentation of research is how the collection by reading and recording documents that exist in the company that has to do with that discussed in this study.

\section{Questionair}

Questionnaire is a method of collecting data by giving or asking questions that have been prepared in advance in the form of questionnaires whose answers are filled directly by the respondents.

\section{Instruments of Data Collection}

The research instrument used to collect data in this research was obtained by distributing questionnaires to employees of Prama Sanur Beach Hotel. Questionnaire distributed to the respondent contains a number of questions written about the items of research variables to get perceptions of the research variables which then answers to questions measured by using a likert scale where respondents are asked to state their perceptions by choosing one of the alternative answers that have a weight or score scores as follows:

Answer SD (Strongly Disagree), scored 1

Answer D (Disagree), scored 2 
Answer LA (Less Agree), scored 3

Answer A (Agree), scored 4

Answers SA (Strongly Agree), scored 5

\begin{abstract}
Methods of Data Analysis Descriptive Analysis

Descriptive analysis serves to describe or give an idea of the object under study through sample data or population as it is, without doing analysis and make conclusions that apply to the public (Sugiyono, 2011). Descriptive analysis is intended to determine the characteristics and responses of respondents to the item questions on the questionnaire. Descriptive analysis also describes the variables in research such as leadership, work environment, employee's working spirit and the performance's employee of Prama Sanur Beach Hotel.
\end{abstract}

\section{Inferential Analysis}

Partial Least Square (PLS) is a more appropriate approach for predictive purposes especially in conditions where indicators are formative. With the latent variable in the form of a linear combination of the indicator, the prediction of the value of the latent variable can be easily obtained, so the prediction of the latent variables it influences can also be easily done. In the PLS the structural model of the relationship between latent variables is called the inner model, whereas the measurement model (reflexive or normative) is called the outer model. The structural model or inner model is evaluated by looking at the percentage of variance described by looking at $\mathrm{R}^{2}$ (R-square exogenous variables) for latent dependent constructs using Stone-Geisser QSquare test size and looking at the magnitude of the structural path coefficients. The stability of this estimate is evaluated using the t-statistic test obtained via the bootstrapping procedure. In contrast to Structural Equation Modeling (SEM), the indicators are reflexive, so the change in the value of an indicator is very difficult to know the value changes of latent variables so that the implementation of predictions is difficult.

\section{RESULT AND DISCUSSION}

The Influence of Leadership on Performance of Employee at Prama Sanur Beach Hotel

Based on the test results, the influence of leadership on employee performance showed leadership positive and insignificant effect on employee performance. This result means that looking at the description of respondents' answers, good leadership is not followed by maximum performance. This insignificant influence can be explained from the characteristics of respondents the majority of respondents have worked over ten years.

The result of this analysis in accordance with the statement put forward by (Nyagaka \& Odongo, 2013) in their researches stated that there is a significant relationship between leadership initiatives to increase leadership style that impact on employee performance.

The result of this study is generally not aligned with previous research findings conducted by (Guterres \& Supartha, 2016), (Makena, 2017), (Ginantra \& Putra, 2015) (Ginantra \& Putra, 2015), and (Eni, 2017) where leadership is important in impacting employee performance.

The Influence of Leadership on Employee Spirit in Prama Sanur Beach Hotel

Based on the test results, the influence of leadership towards the spirit of work shows where leadership has a positive and significant effect towards working spirit. This result means that good leadership supports employee's working spirit.

The results of this analysis in accordance with the statement put forward by (Hasibuan, 2012) which stated that one of the factors that affect the working spirit is leadership. Leadership has an important role in determining employee's working spirit. Because the leader will be an example for his subordinates. Good leadership will affect employee's working spirit in the organization, with a good leadership example then the spirit of work will even good too (Hasibuan, 2012).

The result of this study is generally in line with previous research findings conducted by (Kardiasih, Yasa, \& Sitiari, 2017) and (Mahajaya \& Subudi, 2016) where leadership is important in impacting employee's working spirit.

The Effect of Work Environment on Performance of Employees at Prama Sanur Beach Hotel

Based on the test results, the influence of the work environment on the performance shows that the work environment has a positive and significant effect on the performance. This result means that a good working environment supports employee performance.

The results of this analysis in accordance with the statement from (Sutrisno, 2011) states that the performance of employees in an 
organization is strongly influenced by the work environment. If among employees have not ignored the surrounding environment, then certainly the performance will decrease, so to get a high performance is needed a supportive work environment from the employees.

The result of this study is generally in line with previous research findings conducted by (Putra, 2016), (Mahajaya \& Subudi, 2016) and (Kardiasih et al., 2017) where the work environment is important in impacting employee performance.

The Influence of Work Environment towards Working Spirit of Employees at Prama Sanur Beach Hotel

Based on the test results, the influence of the work environment on working spirit shows where the work environment has a positive and significant effect on working spirit. This result means that a good working environment supports employee's working spirit.

The results of this analysis in accordance with the statement put forward by (Sutrisno, 2011) stated that the work environment can affect the working spirit, with a supportive work environment, employees are expected to continue to strive to improve the working spirit.

The results of this study are generally consistent with previous research findings conducted by (Anteja, 2014), (Permana, 2015), (Hersey, Paul, \& Blancard, 1982) and (Timpe, 1992) which explained that the work environment has an important impact on the employee's working spirit.

The Influence of Working Spirit on Performance of Employee at Prama Sanur Beach Hotel

Based on the test results, the influence of working spirit on the performance shows where the working spirit has positive but not significant effect on the performance. This result means that looking at the description of the respondent's answer, the good of working spirit is not followed by the maximum performance. This insignificant influence can be explained from the characteristics of respondents. The majority of respondents have worked over ten years, although the working spirit is lacking but the employee performance is very good.

The results of this analysis in accordance with the statement put forward by (Rivai, 2013) stating that working spirit is an important operative function of Human Resources Management, because the better the employee's working spirit in the company, the higher the work achievement that can be achieved. Therefore, the working spirit is an important means to achieve the goal, then coaching on working spirit is part of management that very important.

The result of this study is generally not in line with previous research findings conducted by (Kardiasih et al., 2017), (Putra, 2016), (Ginantra \& Putra, 2015) and (Mahajaya \& Subudi, 2016) explaining that spirit of work has an important impact on employee performance.

The Role of Working Spirit in Mediating the Influence of Leadership on Employee Performance at Prama Sanur Beach Hotel

Based on the test results, the role of working spirit in mediating the influence of leadership towards employees' performance at Prama Sanur Beach Hotel stated that working spirit is not a mediation between leadership towards performance, because the direct relationship of leadership to performance is not significant, so also indirect relationship shows that leadership to spirit of work and spirit of work towards performance is also insignificant (Solimun, 2011). This shows that, working spirit is not able to explain the influence of leadership towards employee performance.

\section{The Role of Spirit of Work in Mediating Work Environment Influence Towards Employee Performance at Prama Sanur Beach Hotel}

Based on the test results, the role of working spirit in mediating the influence of work environment on employee performance at Prama Sanur Beach Hotel stated that morale is not mediation between work environment to performance, because the indirect relationship of work spirit to coefficient performance is not significant relationship (Hair et al., 2010). This shows that, working spirit is not able to explain the influence of work environment towards employee performance.

\section{CONCLUSION}

Based on the result and discussion above, the conclusion of this study can be made into:

Leadership has a positive but insignificant influence on performance of Prama Sanur Beach Hotel's employee. This result means that although leadership increases, the performance improvement of employees of Prama Sanur Beach Hotel is not significant. 
Leadership has a positive and significant influence on employee spirit of Prama Sanur Beach Hotel. These results give meaning that good leadership strongly supports employee spirit of Prama Sanur Beach Hotel.

The work environment has a positive and significant influence on the performance of employees of Prama Sanur Beach Hotel. This result means that a good working environment strongly supports the performance improvement of employees of Prama Sanur Beach Hotel.

The work environment has a positive and significant influence on Prama Sanur Beach Hotel's employee spirit. These results mean that a good working environment strongly supports Prama Sanur Beach Hotel's employee spirit.

The spirit of work has a positive influence but insignificant effect on the performance of employees of Prama Sanur Beach Hotel. This result means that although spirit at work is improving, the performance improvement of Prama Sanur Beach Hotel employees is not significant.

The spirit of work is not mediation between leadership and performance, because the direct leadership relationship to performance is insignificant, so the indirect relationship shows that both leadership to spirit at work and spirit at work towards performance is also insignificant.

The spirit of work is not mediation between the work environment on performance, because the indirect relationship of spirit at work to the performance, the relationship coefficient is not significant.

\section{REFERENCES}

Ajzen, I. (1991). Theory of Planned Behavior. Organizational Behavior and Human Decision Processes, 50(2).

Anteja, I. G. ngurah A. P. (2014). Pengaruh Kepemimpinan, Komunikasi, Lingkungan, Kerja terhadap Semangat Kerja Pegawai pada PT. Angkasa Pura Divis Komersial. EJournal Manajemen Universitas Udayana, 3 (2).

Bandura, A. (1977). Social Learning Theory. New Jersey: Prentice-Hall, Inc.

Fishbein, M, \& Ajzen, I. (1975). Belief, Attitude, Intention, and Behavior: An Introduction to Theory and Research. Reading MA: Addison -Wesley.

Ginantra, I. K. G., \& Putra, I. N. W. A. (2015). Pengaruh Ukuran Perusahaan, Profitabilitas, Leverage, Kepemilikan Publik, Dividend Payout Ratio, dan Net Profit Margin pada
Perataan Laba. E-Journal Akuntansi

Universitas Udayana, 10(2).

Guterres, L. A., \& Supartha, W. G. (2016). Pengaruh Gaya Kepemimpinan Dan Motivasi Kerja Terhadap Kinerja Guru. EJurnal Ekonomi Dan Bisnis Universitas Udayana, 5(3). https://doi.org/10.24252/ idaarah.v2i2.6533

Hasibuan, M. S. P. (2012). Manajemen Sumber Daya Manusia: Edisi Revisi. Jakarta: PT Bumi Aksara.

Hersey, Paul, \& Blancard, K. (1982). Management of Organizational Behaviour. New Jersey: Prentice Hall Inc. Englewood Cliffs.

Huang, S., \& Hsu, C. H. . (2009). Effects of Travel Motivation, Past Experience, Perceived Constraint, and Attitude on Re-visit Intention. Journal of Travel Research, 48 (29).

Kardiasih, Yasa, \& Sitiari. (2017). Pengaruh Motivasi Dan Lingkungan Kerja Fisik Terhadap Kepuasan Kerja Dan Kinerja Pegawai Pada Dinas Kebudayaan Kota Denpasar. Jurnal Ekonomi Dan Bisnis Jagadhita, 4(2).

Lee, N. R., \& Kotler, P. (2011). Social Marketing: Influencing Behaviors for Good. US: Sage Publication, Inc.

Mahajaya, G., \& Subudi, M. (2016). Pengaruh Motivasi, Kepemimpinan Dan Lingkungan Kerja Terhadap Kinerja Pegawai Inspektorat Kabupaten Badung. E-Jurnal Manajemen Universitas Udayana, 5(11), 7072-7099.

Mangkunegara, A. P. (2007). Manajemen Sumber Daya Manusia (7th ed.). Bandung: PT Remaja Rosdakary.

Mathis, R. L., \& Jackson, J. H. (2006). Human Resources Management (10th ed.). Jakarta: Salemba Empat.

Moekijat. (2002). Manajemen Tenaga Kerja dan Hubungan Kerja. Bandung: Pionir Jaya.

Nitisemito, A. S. (2001). Manajemen Personalia. Jakarta: Ghalia Indonesia.

Nuraini, T. (2013). Manajemen Sumber Daya Manusia. Pekanbaru: Yayasan Aini Syam.

Nyagaka, E., \& Odongo, A. J. (2013). Leadership Styles of Headteachers and Their Impact on Students' Academic Performance in Secondary Schools, Nyamaiya Division, Nyamira District, Kenya. Journal of Educational and Social Research MCSER Publishing, 3(3).

Putra, D. G. A. P. (2016). Pengaruh Iklim Organinasi Dan Motivasi Terhadap Kepuasan Kerja Dan Kinerja Karyawan Tjendana Mandra Sakti (TMS) Tours.

Rivai, V. (2013). Manajemen Sumber Daya Manusia Untuk Perusahaan. Jakarta: PT Raja Grafindo Persada.

Sedarmayanti. (2004). Sumber Daya Manusia dan Produktivitas Kerja. Bandung: Mandar Maju. 
Solimun. (2011). Analisis Variabel Moderasi Dan Mediasi. Program Studi Statistika FMIPA UB $31 \mathrm{~V}$.

Sugiyono. (2011). Metode Penelitian Administratif. Bandung: Alfabeta.

Sugiyono. (2013). Metode Penelitian Pendidikan Pendekatan Kuantitatif, Kualitatif, dan $R \& D$. Bandung: Alfabeta.

Sugiyono. (2016). Metode Penelitian Kuantitatif, Kualitatif dan R\&D. Bandung: PT Alfabeta.

Sugiyono. (2017). Metode Penelitian Kuantitatif, Kualitatif, dan $R \& D$. Bandung: Alfabeta.

Sutrisno, E. (2011). Manajemen Sumber Daya Manusia. Jakarta: Kencana Pranada Media Group.

Thoha, M. (2010). Kepemimpinan Dalam Manajemen. Jakarta: PT. Raja Grafindo Persada.

Timpe, A. D. (1992). The Art and Science of Business Management Performance. Mumbai: Jaico Publishing House.

Umar, H. (2013). Desain Penelitian MSDM dan Prilaku Karyawan. Jakarta: PT Raja Grafindo Persada.

Ajzen, I. (1991). Theory of Planned Behavior. Organizational Behavior and Human Decision Processes, 50(2).

Anteja, I. G. ngurah A. P. (2014). Pengaruh Kepemimpinan, Komunikasi, Lingkungan, Kerja terhadap Semangat Kerja Pegawai pada PT. Angkasa Pura Divis Komersial. EJournal Manajemen Universitas Udayana, 3 (2).

Bandura, A. (1977). Social Learning Theory. New Jersey: Prentice-Hall, Inc.

Fishbein, M, \& Ajzen, I. (1975). Belief, Attitude, Intention, and Behavior: An Introduction to Theory and Research. Reading MA: Addison -Wesley.

Ginantra, I. K. G., \& Putra, I. N. W. A. (2015). Pengaruh Ukuran Perusahaan, Profitabilitas, Leverage, Kepemilikan Publik, Dividend Payout Ratio, dan Net Profit Margin pada Perataan Laba. E-Journal Akuntansi Universitas Udayana, 10(2).

Guterres, L. A., \& Supartha, W. G. (2016). Pengaruh Gaya Kepemimpinan Dan Motivasi Kerja Terhadap Kinerja Guru. EJurnal Ekonomi Dan Bisnis Universitas Udayana, 5(3). https://doi.org/10.24252/ idaarah.v2i2.6533

Hasibuan, M. S. P. (2012). Manajemen Sumber Daya Manusia: Edisi Revisi. Jakarta: PT Bumi Aksara.

Hersey, Paul, \& Blancard, K. (1982). Management of Organizational Behaviour. New Jersey: Prentice Hall Inc. Englewood Cliffs.

Huang, S., \& Hsu, C. H. . (2009). Effects of Travel Motivation, Past Experience, Perceived Constraint, and Attitude on Re-visit Intention. Journal of Travel Research, 48 (29).
Kardiasih, Yasa, \& Sitiari. (2017). Pengaruh Motivasi Dan Lingkungan Kerja Fisik Terhadap Kepuasan Kerja Dan Kinerja Pegawai Pada Dinas Kebudayaan Kota Denpasar. Jurnal Ekonomi Dan Bisnis Jagadhita, 4(2).

Lee, N. R., \& Kotler, P. (2011). Social Marketing: Influencing Behaviors for Good. US: Sage Publication, Inc.

Mahajaya, G., \& Subudi, M. (2016). Pengaruh Motivasi, Kepemimpinan Dan Lingkungan Kerja Terhadap Kinerja Pegawai Inspektorat Kabupaten Badung. E-Jurnal Manajemen Universitas Udayana, 5(11), 7072-7099.

Mangkunegara, A. P. (2007). Manajemen Sumber Daya Manusia (7th ed.). Bandung: PT Remaja Rosdakary.

Mathis, R. L., \& Jackson, J. H. (2006). Human Resources Management (10th ed.). Jakarta: Salemba Empat.

Moekijat. (2002). Manajemen Tenaga Kerja dan Hubungan Kerja. Bandung: Pionir Jaya.

Nitisemito, A. S. (2001). Manajemen Personalia. Jakarta: Ghalia Indonesia.

Nuraini, T. (2013). Manajemen Sumber Daya Manusia. Pekanbaru: Yayasan Aini Syam.

Nyagaka, E., \& Odongo, A. J. (2013). Leadership Styles of Headteachers and Their Impact on Students' Academic Performance in Secondary Schools, Nyamaiya Division, Nyamira District, Kenya. Journal of Educational and Social Research MCSER Publishing, 3(3).

Putra, D. G. A. P. (2016). Pengaruh Iklim Organinasi Dan Motivasi Terhadap Kepuasan Kerja Dan Kinerja Karyawan Tjendana Mandra Sakti (TMS) Tours.

Rivai, V. (2013). Manajemen Sumber Daya Manusia Untuk Perusahaan. Jakarta: PT Raja Grafindo Persada.

Sedarmayanti. (2004). Sumber Daya Manusia dan Produktivitas Kerja. Bandung: Mandar Maju.

Solimun. (2011). Analisis Variabel Moderasi Dan Mediasi. Program Studi Statistika FMIPA UB $31 \mathrm{~V}$.

Sugiyono. (2011). Metode Penelitian Administratif. Bandung: Alfabeta.

Sugiyono. (2013). Metode Penelitian Pendidikan Pendekatan Kuantitatif, Kualitatif, dan $R \& D$. Bandung: Alfabeta.

Sugiyono. (2016). Metode Penelitian Kuantitatif, Kualitatif dan R\&D. Bandung: PT Alfabeta.

Sugiyono. (2017). Metode Penelitian Kuantitatif, Kualitatif, dan $R \& D$. Bandung: Alfabeta.

Sutrisno, E. (2011). Manajemen Sumber Daya Manusia. Jakarta: Kencana Pranada Media Group.

Thoha, M. (2010). Kepemimpinan Dalam Manajemen. Jakarta: PT. Raja Grafindo Persada. 
The Effect Of Attitude, Normal Subjective And Perceived Behavioral Control (Pbc) On Actual Purchasing Through Purchases Of Online Purchase In The Online Retail Industry

Timpe, A. D. (1992). The Art and Science of Business Management Performance. Mumbai: Jaico Publishing House.

Umar, H. (2013). Desain Penelitian MSDM dan Prilaku Karyawan. Jakarta: PT Raja Grafindo Persada. 